\title{
A Graphical User Interface for the Visually Impaired - an Evaluation
}

\author{
D. Veal (Corresponding author) \\ School of Computer Science and Security Science, Edith Cowan University \\ 2 Bradford Street, Mount Lawley, Western Australia, 6050, Australia \\ Tel: 61-8-9370-6295Ｅ-mail: d.veal@ecu.edu.au \\ S. P. Maj \\ School of Computer Science and Security Science, Edith Cowan University \\ 2 Bradford Street, Mount Lawley, Western Australia, 6050, Australia \\ Tel: 61-8-9370-6277Ｅ-mail: p.maj@ecu.edu.au
}

\begin{abstract}
The majority of visually impaired blind and deafblind people retain some degree of residual vision. Software called Dynamic Pattern System (DPS) was developed to utilize this residual vision by generating a range of different patterns, colors and shapes unique to each individual's residual vision - called a pattern set. This pattern set can then be mapped to printable alphanumeric characters. Limited trials with the visually impaired suggested DPS may have value. This paper is a more detailed evaluation of DPS undertaken by a normally sighted person using low vision simulators that mimic different visual handicap conditions.
\end{abstract}

Keywords: Visually Impaired, Graphical User Interface (GUI), Assistive Technology

\section{Blindness - a global problem}

Globally there are over 314 million visually impaired people; 45 million of them are totally blind. The World Health Organization (WHO) uses a classification scheme to define the degree of visual impairment after the best corrective lenses have been used. A visual acuity of $6 / 60$ (persons who can read at 6 meters material legible to a fully sighed person at 60 meters) is considered as severe visual impairment. Visual acuity is a quantitative measure of the spatial resolution of the eye (Figure 1). Normal sightedness is defined as 6/6. The imperial 20/20 metric is also employed. Significantly only a small percentage of the visually handicapped are totally blind (RBS, 1996).

There is an aging workforce and older people are likely to have vision impairment. According to the American Foundation for the Blind (AFB),

'A rapidly increasing proportion of the aging population experiences eye problems that make simple daily tasks difficult or impossible, even when wearing glasses or contact lenses. Severe eye problems are not just a matter of "getting older". The risk of severe eye problems has been found to increase significantly with age, particularly in those over age $65^{\prime}$ (AFB, 2008, p. 1).

According to WHO worldwide more than $82 \%$ of the blind are over 50 years of age and that age-related macular degeneration which involves the loss of the central field of vision is a leading cause of age related blindness worldwide (WHO, 2010). Significantly many developed countries have a rapidly aging profile. Within some countries, such as Australia, indigenous people have a higher incidence of blindness (Vision20/20, 2007).

Furthermore there are many research findings to indicate increasing blindness with the increasing incidence of diabetes (NIH, 2009) the most common cause of blindness in the under 60's (Zimmet, 2008). Diabetes is on the rise worldwide and in Australia it has been estimated there will be 1.23 million diabetics by 2010 Zimmet, 2008). Diabetic retinopathy leads to progressive damage to the eye's retina and can eventually cause blindness. Almost all people who have had diabetes for more than 30 years will exhibit signs of diabetic retinopathy (VCM, 2010).

There are also many cases of legalization worldwide to assist in providing some protection for the disabled including the blind and deaf blind, for example, within Australia, the Disability Discrimination Act 1992 which covers sensory disabilities (AHRC, 2010). Within the USA there is the Americans with Disabilities Act (ADA) (Ladner, 1989; DoJ, 1994; DoJ, 2008) and in the UK there is the Disability Discrimination Act (Crown, 2005). Within Ontario Canada there is the Ontarians with Disabilities Act, 2001 (Ontario, 2007). 


\subsection{Social and Economic Impacts}

Social and economic inclusivity depends upon visual communication - signs, text, images, Internet, email etc. An individual's ability to use visual information is crucial to participation in the community at large. According to Fewtrell:

'Participation in the broader community depends on the individual capacity to receive and use visually-based information. Limited access to visually-based information affects all aspects of the lives of people who are blind or vision impaired.' (Fewtrell, 1998, p. 10).

Interaction with text-based materials is therefore of paramount importance for participation in the workforce and to engage with society as a whole. It is therefore imperative to enable people with visual impairments to participate in the workforce and to engage with society as a whole. Susana et al note that "Reading is critical to participation in modern society" (Susana, Chung, Mansfield, \& Legge, 1998, p.2949). However, for many, visual reading is not possible using standard fonts - within Australia only 3 to 5\% of print material is in accessible format (Vision, 2009a).

In Australia there are lower employment rates for those with vision loss and in 2009 the total financial cost as estimated by Access Economics was $\$ 7.2$ billion which was $\$ 12,556$ for each individual with vision loss (Access-Economics, 2009 and software that could enable more people who have some remaining residual vision to participate, or continue to participate, in the workforce is of both high economic as well as social importance.

\subsection{Assistive Technologies for the Blind and Deafblind}

Braille is the dominant assistive technology for the visually impaired. This uses a system of embossed or raised signs, which are formed by six dots arranged as in the Braille cell. Braille devices are commonly used but are expensive and have a steep learning curve due to the tactile nature of the media and may therefore be unsuitable for many with head injury or stroke effects. Similar conditions also exist for the aged. Automatic text-to-speech devices are useful but can be problematic for the deaf-blind (Leuterman, 2002; Vision, 2009b). People who suffer from Diabetic Peripheral Polyneuropathy (DPP), a major cause of blindness causes a loss of sensitivity in the fingertips which can exclude the use of Braille (NIH, 2009). The problem of moving away from vision as the main information input is the high efficiency of sight in coping with large amounts of material that other senses lack. According to Edwards:

'...the fundamental problem is that sight is very efficient. This is often summarized (somewhat loosely) by saying that sight has a very broad bandwidth... they present a lot of material on the screen but rely on the power of sight to cope with it all. None of the non-visual senses has that same power, that bandwidth' (Edwards, 1995, p. 46).

Furthermore the persistence of an image in the eye of the user could make it available for mental processing even after its cause has ceased (Neisser, 1967) which may assist their interpretation of visually based information.

\section{Dynamic Pattern System (DPS)}

\subsection{DPS introduction}

A proof of concept software called Dynamic Pattern System (DPS) was written and preliminary trials conducted with the Royal WA Institute for the Blind - now known as Senses Foundation. This work demonstrated that DPS could be used by the visually impaired however further work is needed (Veal, Maj, \& Makasiranondh, 2009; Veal, 2007; Veal \& Maj, 2005; Veal, Maj \& Kohli, 2004; Veal \& Maj, 2001). The DPS software allows sighted users to create a limited number of colored shapes of various sizes. Each unique pattern, matched to the residual vision of the blind person, is used to represent an alphanumeric character, word or a sign. The complete set of patterns of area sizes area colors size, on screen area placement, pattern inter pattern and inter-word presentation times and the pattern's background color representing the alphanumeric character set is known as a pattern-set.

\subsection{DPS display characteristics}

A word can be read using the DPS as a displayed sequence of s patterns presented at a given speed on screen where each pattern, representing an alphanumerical character, held on screen for a given time period. This time period as well as the time period between words can also be adjusted as a multiple of the character presentation time and can give the character presentation a rhythm that can assist in the recognition process in a manner similar to popular methods of learning Morse code (AA9PW, 2010). In effect each vision impaired person has their own individual GUI based pattern-set suited to their own visual ability. Such matching is attained by presenting users with a range component area sizes, and the distances between the areas as well as finding the most convenient and background color for their comfort and ease of recognition. It should also be noted that as with conventional fonts where the size of a font can also effect reading speed (Susana Chung Mansfeild \& 
Legge, 1998) initial findings also confirmed this to be the case with the DPS patterns.

A pattern matching screen is shown in Figure 2. For certain visual impairments this could mean setting the shapes to be at the edges of the screen or only within a given triangle of on screen area. The color combinations for the shapes can then be adjusted likewise and set. The pattern presentation times are also varied and changed later to allow for faster reading speeds. The most easily recognized patterns were use to represent the most commonly occurring characters in English which is similar to Morse code which uses the shortest number of dots or dashes to represent such characters. As the user enters text the pattern representing last entered character appears on screen. The text can be read back at a given speed of on-screen pattern presentation or other text can be loaded from a file and then read in a similar manner. Each pattern can be displayed on a computer screen or displayed on a much larger surface via a computer projector. A pattern could take up the whole of a computer or a computer projector screen Figure 3. The controls, text box and character display box can be selectively hidden when the system is being used to present patterns to volunteers with visual impairments. The DPS can be used to read or write information in pattern based format. However, as the present version of DPS was designed to be used with a facilitator or researcher its menu system also needs to be pattern based and to be more fully integrated into existing applications such as word processing, spreadsheet and email applications.

\subsection{The key research findings}

These were:

1) DPS can be uniquely customized to the residual vision of each individual including reading speeds and delay time between words. Alphanumeric characters automatically converted to and from a pattern set.

2) DPS software runs on a standard PC and individual pattern sets can be saved and then automatically loaded for each person.

3) As it is not uncommon for visual ability to deteriorate their pattern-set is adaptive and can be modified to accommodate changes in an individual's residual vision (i.e. the pattern set can be modified). (Veal \& Maj, 2005).

\subsection{DPS design: Some decisions and outcomes}

The present version of the DPS software only allows a maximum of five on on-screen colored shapes to represent a pattern with the background color kept constant for a particular patternset. The reason for this was based on the assumption that if a visually disabled person could see more than this number of patterns per screen then they would be able to see enlarged standard characters. The design of the DPS allows ASCII characters and their matching pattern details to be stored as a text file and reloaded and displayed on screen at rates given by information also stored in this file.

To assist the pattern recognition and pattern to character association by volunteers it was decided to only have a single patter to represent both upper and lower case textual characters.

\section{Dynamic Pattern System (DPS) - evaluation using low vision simulators}

In order to further evaluate DPS low vision simulators were obtained. Such low vision simulators are goggles (VRS, 2010), that when worn by normally sighted individuals simulate different types of visual impairment (Table 1). For some conditions such as impaired acuity a range of conditions were tested. Use of these goggles allowed a range of visual impairments to be rapidly evaluated using DPS before such changes are evaluated using blind and deafblind volunteers. These goggles are designed to be worn over any glasses on a normally sighted person to allow them to visually experience the effects due the goggles and not mix this effect with any limitations that the glasses were intended to help to alleviate. A fully sighted person wore the different low vision simulators and viewed a range of different sized colored shapes displayed on a computer screen $(380 \times 300 \mathrm{~mm})$ and results evaluated (Table 2). For most of the simulated conditions tested it was possible to view normal or enlarged fonts (Times New Roman point) although often this was only with a degree of difficulty. However for diabetic retinopathy, central scotoma and impaired acuity (20/800) it was not possible to see even the largest possible font size. Significantly all these three conditions can see the full color DPS spectrum and also distinct shapes (circle, square). Using these results it is now possible to recruit the visually impaired with those conditions and further evaluate the DPS software. A newer version of the DPS with more than five colored areas per pattern is intended to be developed to match fonts more fully to the residual version of those who although can see enlarged fonts may be with some difficulty.

\section{Conclusions}

DPS could be of use for a range of vision conditions. Further research and software development is needed to 
make such a system more usable by the blind and deafblind. This includes the use of a menu system which is also pattern based and to be integrated into existing IT applications. Use of goggles allowed a range of visual impairments to be rapidly evaluated using DPS which could enable the research and software processes to be undertaken by the researches and software developers before final evaluation on a blind and deafblind volunteer population which could lessen the impost on their time. A new version of the DPS will also incorporate more areas per pattern help provide better matched fonts for those who can see enlarged fonts.

\section{References}

AA9PW. (2010). AA9PW FCC Exam practice amateur radio and commercial radio licensing exam practice, from http://aa9pw.com/

Access Economics. (2009). Clear focus: The economic impact of vision loss in Australia in 2009. The full report prepared for Vision 2020 Australia, from http://www.vision2020australia.org.au/resources.cfm?\&page=1.

AFB. (2008). Special report on aging and vision loss, 2010, from

http://www.afb.org/Section.asp?SectionID=15\&DocumentID=4423

Crown. (2005). Disability Discrimination Act 2005, from

http://www.opsi.gov.uk/Acts/acts2005/ukpga_20050013_en_1

DoJ. (1994). ADA Standards for accessible design, 2007, from www.usdoj.gov/crt/ada/adastd94.pdf

DOJ. (2008). Americans with disabilities act of 1990 as amended. Retrieved December 9, 2009, from www.ada.gov/pubs/adastatute 08 .htm

Edwards, A. D. N. (1995). The rise of the graphical user interface. Information Technology and Disabilities., 2(4). 46-50.

Fewtrell, B. (1998). Equitable access for the visually impaired. Incite, 10.

Ladner, R. E. (1989). Computer accessibility for federal workers with disabilities: It's the law. . Communications of the $A C M, 32(8), 952-956$.

Leuterman, D. M. (2002). When your child is deaf: A guide for parents. Parkton, MD: York Press.

Neisser, U. (1967). Cognitive psychology. Englewood Cliffs, NJ: Prentice-Hall.

NIH. (2009). Your Guide to Diabetes: Type 1 and Type 2. Retrieved August 9, 2010, from

http://diabetes.niddk.nih.gov/dm/pubs/type1and2/

Ontario. (2007). Service Ontario e-Laws: Chapter 32 Ontarians with Disabilities Act, 2001: Government of Ontario, Canada.

RBS. (1996). "When even glasses don't help" A study of the needs of people who are blind or vision impaired. Sydney Australia: Royal Blind Society (RBS) of NSW.

Susana, T. L., Chung, J., Mansfield, S., \& Legge, G. E. (1998). The effect of print size on reading speed in normal peripheral vision. Vision Research, 38 (19), 2949-2962.

VCM. (2010). What is Diabetic Retinopathy? Retrieved September 16, 2010, from

http://www.virtualmedicalcentre.com/diseases.asp?did=652\#What_is

Veal, D., \& Maj, S. P. (2001, October). A computer interface for the "blind" using dynamic patterns. Paper presented at the International Conference on Computing and Information Technologies (ICCIT'2001), Montclair State University, NJ.

Veal, D., Maj, S. P., \& Kohli, G. (2004). A narrow bandwidth GUI for diagram recognition by the blind. Paper presented at the American Society for Engineering Education (ASEE), 2004 Annual Conference, Salt Lake City, UT.

Veal, D., \& Maj, S. P. (2005). A new visual communication system for deaf-blind tertiary education students.

Paper presented at the 4th Global Colloquium on Engineering Education., Sydney, NSW, Australia.

Veal, D., Maj, S. P., \& Makasiranondh, W. (2009). Dynamic patterns for low vision internetworking students. World Transactions on Engineering and Technology Education. WIETE, 7(2), 5.

Veal., D. (2007). Improving security for vision impaired ATM access via dynamic patterns. In D. Li (Ed.), Sixth International Workshop for Applied PKC (IWAP07). Perth Australia: ECU.

Vision20/20. (2007). Aboriginal and Torres Strait Islander eye care fact sheet (August 2807 ed.): Vision20/20. 
Vision, A. (2009a). Blindness and low vision in Australia. Retrieved Sept 1, 2010, from http://www.visionaustralia.org.au/info.aspx?page=1136\&template=PrintReg

Vision, A. (2009b). Eye conditions. Retrieved September 2, 2010, from http://www.visionaustralia.org/info.aspx?page $=1136$

VRS (2010). Low vision simulators. Retrieved September 3, 2010, from

http://www.lowvisionsimulators.com/

WHO. (2010). Magnitude of blindness and visual impairment. Retrieved 20/8/2010, 2010, from http://www.who.int/blindness/causes/magnitude/en/index.html

Zimmet, P. (2008). Diabetes Mellitus - One of Australia's top six health priorities. Retrieved August 19, 2010, from http://www.healthinsite.gov.au/expert/Diabetes_Mellitus One_of_Australia_s_top_six_health_priorities

Table 1. Range of visual impairment conditions

\begin{tabular}{|l|l|}
\hline Condition & Comments \\
\hline $\begin{array}{l}\text { Diabetic } \\
\text { Retinopathy }\end{array}$ & $\begin{array}{l}\text { Series of progressive retinal changes accompanying long standing diabetes } \\
\text { mellitus. }\end{array}$ \\
\hline $\begin{array}{l}\text { Left } \\
\text { Homonymous } \\
\text { Hemianopsia }\end{array}$ & $\begin{array}{l}\text { Visual field defect (blind area) affecting the same half (left) of each eye's field. } \\
\text { Caused by an abnormality (e.g. brain tumor, vascular lesion). }\end{array}$ \\
\hline $\begin{array}{l}\text { Right } \\
\text { Hemomianopsia }\end{array}$ & $\begin{array}{l}\text { Visual field defect (blind area) affecting the same half (right) of each eye's field. } \\
\text { Caused by an abnormality (e.g. brain tumor, vascular lesion). }\end{array}$ \\
\hline $\begin{array}{l}\text { Impaired Acuity } \\
\text { Quantifiable measure of deterioration in ability of eye to distinguish object details } \\
\text { and shape. }\end{array}$ \\
\hline $\begin{array}{l}\text { Central Scotoma } \\
\text { Tunnel Vision, } \\
\text { visual field 20 } \\
\text { degrees }\end{array}$ & $\begin{array}{l}\text { Lon-seeing area within the (central) visual field. May be normal (physiological) or } \\
\text { may result from damage to the retina or to the visual pathways. }\end{array}$ \\
\hline
\end{tabular}


Table 2. Results of fully sighted person viewing DPS

\begin{tabular}{|c|c|c|c|c|}
\hline Condition & $\begin{array}{l}\text { Visual } \\
\text { Acuity }\end{array}$ & DPS colors & DPS shapes & Comments \\
\hline $\begin{array}{l}\text { Diabetic } \\
\text { Retinopathy }\end{array}$ & $\begin{array}{l}20 / 100 \\
6 / 30\end{array}$ & $\begin{array}{l}\text { Full color spectrum } \\
\text { visible }\end{array}$ & $\begin{array}{l}\text { Distinct shapes } \\
\text { visible. }\end{array}$ & $\begin{array}{l}\text { Very difficult to see even } \\
\text { enlarged fonts e.g. } 72 \text { point }\end{array}$ \\
\hline $\begin{array}{l}\text { Left } \\
\text { Homonymous } \\
\text { Hemianopsia }\end{array}$ & $\begin{array}{l}20 / 200 \\
6 / 60\end{array}$ & $\begin{array}{l}\text { Full color spectrum } \\
\text { visible }\end{array}$ & $\begin{array}{l}\text { Distinct shapes } \\
\text { visible. }\end{array}$ & $\begin{array}{l}\text { Enlarged font ( } 48 \text { point) } \\
\text { visible, but restricted field } \\
\text { of vision }\end{array}$ \\
\hline $\begin{array}{l}\text { Right } \\
\text { Homonymous } \\
\text { Hemianopsia }\end{array}$ & $\begin{array}{l}20 / 200 \\
6 / 60\end{array}$ & $\begin{array}{l}\text { Full color spectrum } \\
\text { visible }\end{array}$ & $\begin{array}{l}\text { Distinct shapes } \\
\text { visible. }\end{array}$ & $\begin{array}{l}\text { Enlarged font ( } 48 \text { point) } \\
\text { visible, but restricted field } \\
\text { of view }\end{array}$ \\
\hline $\begin{array}{l}\text { Impaired } \\
\text { Acuity }\end{array}$ & $\begin{array}{l}20 / 80 \\
6 / 24\end{array}$ & $\begin{array}{l}\text { Full color spectrum } \\
\text { visible }\end{array}$ & $\begin{array}{l}\text { Distinct shapes } \\
\text { visible. }\end{array}$ & $\begin{array}{l}\text { Enlarged font ( } 20 \text { point }) \\
\text { visible }\end{array}$ \\
\hline $\begin{array}{l}\text { Impaired } \\
\text { Acuity }\end{array}$ & $\begin{array}{l}20 / 200 \\
6 / 60\end{array}$ & $\begin{array}{l}\text { Full color spectrum } \\
\text { visible }\end{array}$ & $\begin{array}{l}\text { Distinct shapes } \\
\text { visible. }\end{array}$ & $\begin{array}{l}\text { Enlarged font ( } 48 \text { point) } \\
\text { visible }\end{array}$ \\
\hline $\begin{array}{l}\text { Impaired } \\
\text { Acuity }\end{array}$ & $\begin{array}{l}20 / 400 \\
6 / 120\end{array}$ & $\begin{array}{l}\text { Full color spectrum } \\
\text { visible }\end{array}$ & $\begin{array}{l}\text { Distinct shapes } \\
\text { visible. }\end{array}$ & $\begin{array}{l}\text { Enlarged font ( } 72 \text { point) } \\
\text { visible }\end{array}$ \\
\hline $\begin{array}{l}\text { Impaired } \\
\text { Acuity }\end{array}$ & $\begin{array}{l}20 / 800 \\
6 / 240\end{array}$ & $\begin{array}{l}\text { Full color spectrum } \\
\text { visible }\end{array}$ & $\begin{array}{l}\text { Distinct shapes } \\
\text { visible. }\end{array}$ & $\begin{array}{l}\text { Not even enlarged fonts } \\
\text { visible }\end{array}$ \\
\hline $\begin{array}{l}\text { Central } \\
\text { Scotoma }\end{array}$ & $\begin{array}{l}20 / 200 \\
6 / 60\end{array}$ & $\begin{array}{l}\text { Full color spectrum } \\
\text { visible }\end{array}$ & $\begin{array}{l}\text { Distinct shapes } \\
\text { visible. }\end{array}$ & $\begin{array}{l}\text { Enlarged font ( } 48 \text { point) } \\
\text { visible, but restricted field } \\
\text { of view }\end{array}$ \\
\hline $\begin{array}{l}\text { Central } \\
\text { Scotoma }\end{array}$ & $\begin{array}{l}20 / 400 \\
6 / 120\end{array}$ & $\begin{array}{l}\text { Full color spectrum } \\
\text { visible }\end{array}$ & $\begin{array}{l}\text { Distinct shapes } \\
\text { visible. }\end{array}$ & $\begin{array}{l}\text { Not even enlarged fonts } \\
\text { visible }\end{array}$ \\
\hline $\begin{array}{l}\text { Tunnel Vision, } \\
\text { visual field } 20 \\
\text { degrees }\end{array}$ & $\begin{array}{l}20 / 80 \\
6 / 24\end{array}$ & $\begin{array}{l}\text { Full color spectrum } \\
\text { visible }\end{array}$ & $\begin{array}{l}\text { Distinct shapes } \\
\text { visible. }\end{array}$ & $\begin{array}{l}\text { Normal text but only } \\
\text { within extremely restricted } \\
\text { field of vision }\end{array}$ \\
\hline $\begin{array}{l}\text { Tunnel Vision, } \\
\text { visual field } 10 \\
\text { degrees }\end{array}$ & $\begin{array}{l}20 / 80 \\
6 / 24\end{array}$ & $\begin{array}{l}\text { Full color spectrum } \\
\text { visible }\end{array}$ & $\begin{array}{l}\text { Distinct shapes } \\
\text { visible. }\end{array}$ & $\begin{array}{l}\text { Normal text but only } \\
\text { within extremely restricted } \\
\text { field of vision }\end{array}$ \\
\hline
\end{tabular}

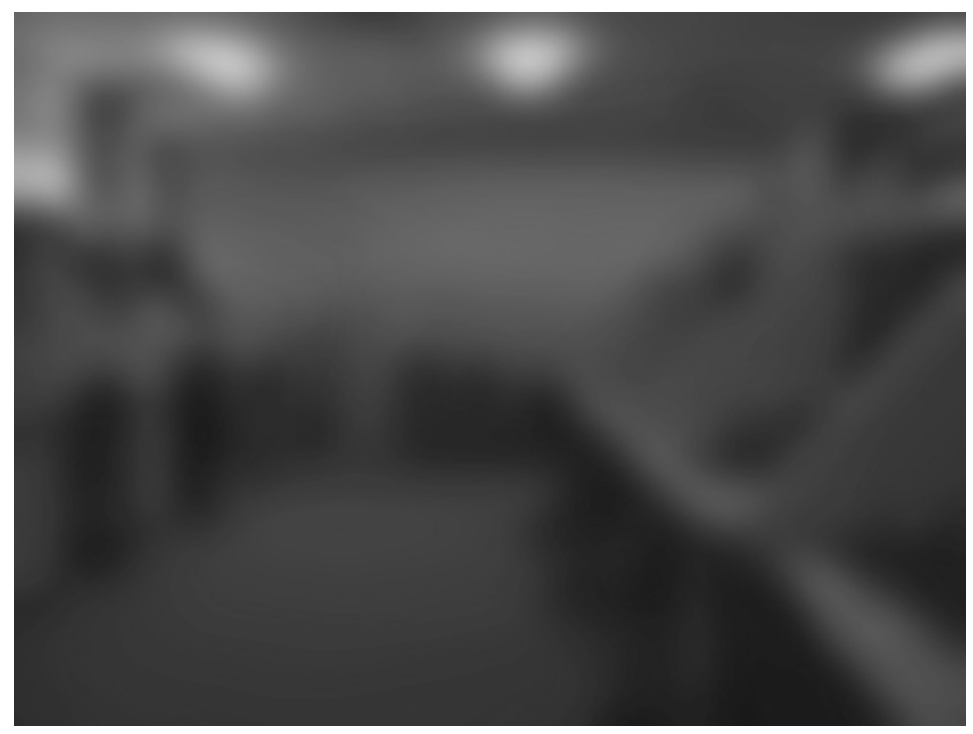

Figure 1. Residual Vision for 20/800 (imperial) after best possible corrective lenses. 


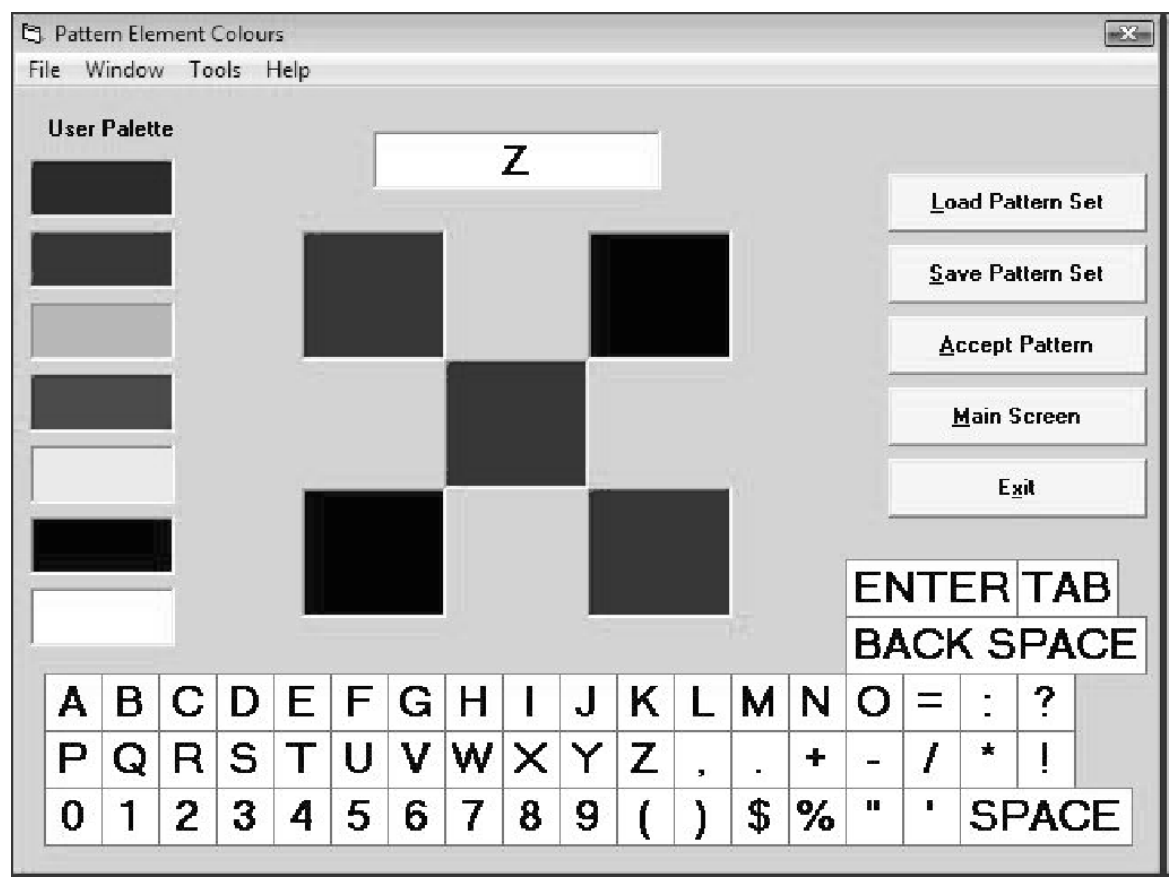

Figure 2. The DPS Pattern Matching Screen.

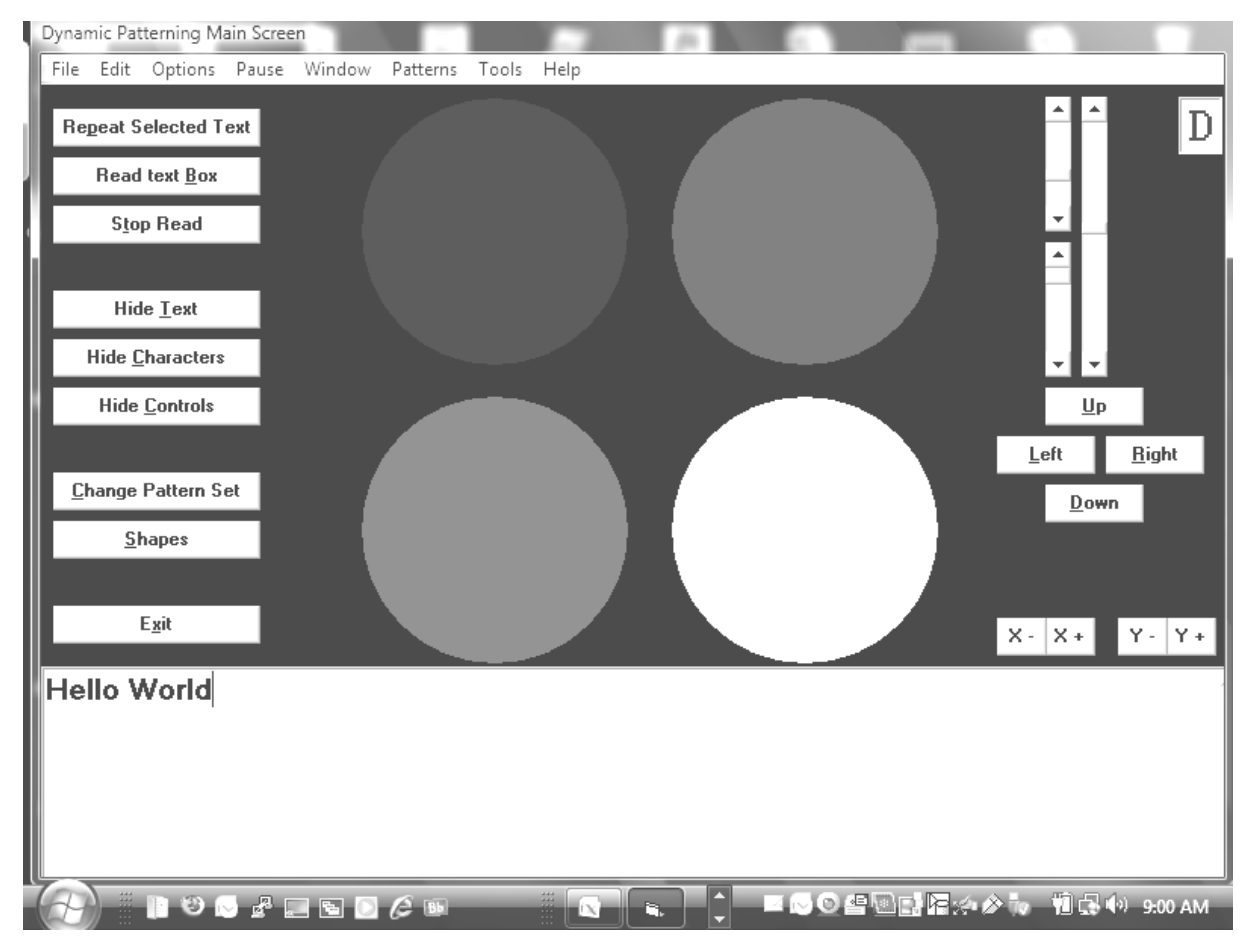

Figure 3. A DPS Pattern Presentation Screen. 